\title{
METODOLOGIA DE RESOLUÇÃO DE SITUAÇÃO-PROBLEMA APLICADA À AULA DE PRODUÇÃ̃ DE TEXTO NO ENSINO MÉDIO
}

\author{
METODOLOGÍA DE RESOLUCIÓN DE PROBLEMA APLICADA A LA CLASEDE \\ PRODUCCIÓN DE TEXTO EN LA ESCUELA SECUNDARIA
}

\author{
PROBLEM-SITUATION RESOLUTION METHODOLOGY APLLIED TO THE \\ WRITING CLASS IN HIGH SCHOOL
}

\author{
Maria Teresa Martins GUIRADO ${ }^{1}$ \\ Rosebelly Nunes MARQUES ${ }^{2}$ \\ Flávia Pierrotti de CASTRO ${ }^{3}$
}

RESUMO: Este trabalho refletiu sobre ensino-aprendizagem de redação no Ensino Médio a partir do uso de metodologias ativas, especialmente, resolução de situação-problema. $\mathrm{O}$ primeiro objetivo foi analisar a aplicação de metodologias ativas em aulas de redação na $3^{\mathrm{a}}$ série do Ensino Médio em um colégio privado no interior de São Paulo. Posteriormente, a partir das reflexões geradas pelas atividades, o objetivo foi produzir uma sequência didática voltada à orientação de professores de produção de texto que pudesse contribuir com o ensino-aprendizagem de produção escrita na educação básica. A metodologia empregada baseou-se em pesquisa-ação (FRANCO, 2005), metodologias ativas (MACEDO, 2005) e construção de sequências didáticas (GUIMARÃES; GIORDAN, 2011; ZABALA, 1998). Também foi usada uma adaptação da metodologia das simulações de assembleias da ONU. Em geral, os alunos tiveram um ganho expressivo no desempenho de suas habilidades argumentativas, em produção orais e escritas, refletindo sobre autonomia, empatia, direitos humanos e consenso. Porém, as atividades levantaram a necessidade da ampliação do uso de tais metodologias e de situações didáticas que estimulem a autonomia em séries anteriores, não só no final do ciclo. Quanto à construção da sequência didática, mostrou-se um caminho produtivo para dividir a experiência e ampliar a discussão sobre as metodologias ativas, além de essencial para passar-se de uma prática intuitiva para uma prática reflexiva. Por fim, a pesquisa deixou claro que o campo é frutífero para muitas reflexões e transformações sobre ensino-aprendizagem de redação.

PALAVRAS-CHAVE: Autonomia. Sequência-didática. Redação. Formação de professores.

\footnotetext{
${ }^{1}$ Programa de Educação Continuada em Economia e Gestão de Empresas (PECEGE-ESALQ), Piracicaba - SP Brasil. Pós em Gestão Escolar. ORCID: https://orcid.org/0000-0002-4357-9185. E-mail: mate_martins@hotmail.com

${ }^{2}$ Universidade de São Paulo (USP/ ESALQ), Piracicaba - SP - Brasil. Docente do Departamento de Economia, Administração e Sociologia (LES/ESALQ). ORCID: https://orcid.org/0000-0002-8726-3211. E-mail: rosebelly.esalq@usp.br

${ }^{3}$ Universidade Federal de São Carlos (UFSCar), São Carlos - SP - Brasil. Programa de Educação Continuada em Economia e Gestão de Empresas (PECEGE-ESALQ), Piracicaba - SP - Brasil. Doutoranda do Programa de Pós-Graduação em Química. ORCID: https://orcid.org/0000-0002-7977-8709. E-mail: flavia_pierrotti@yahoo.com.br
} 
RESUMEN: Este trabajo reflejó sobre enseñanza de redacción en el $3^{\circ}$ año de la escuela secundária a través de metodologías activas, especialmente, resolución de situación problema. El primer objetivo fue analizar la aplicación de metodologías activas en clases de redacción en una escuela privada en interior de São Paulo. Posteriormente, a partir de las reflexiones generadas por las actividades, el objetivo fue producir una secuencia didáctica centrada en la orientación de los maestros de producción de texto que podría contribuir a la enseñanza de redacción. La metodología empleada estaba basada en investigación de acción (FRANCO, 200;), metodologías activas (MACEDO, 2005) y construcción de secuencias didácticas (GUIMARÃES; GIORDAN, 2011; ZABALA, 1998;). También se utilizó una adaptación de la metodología de simulación de la Asamblea de la ONU. En general, los estudiantes tuvieron una ganancia significativa en el desempeño de habilidades argumentativas, en producciones orales y escritas, reflexionando sobre autonomía, empatía, derechos humanos y consenso. Sin embargo, las actividades plantearon la necesidad de ampliar el uso de tales metodologías y situaciones didácticas que fomentan la autonomía en series anteriores, no solo al final del ciclo. En cuanto a la construcción de la secuencia didáctica, resultó ser una forma productiva de compartir la experiencia y ampliar la discusión sobre metodologías activas, resultó aún esencial para pasar de una práctica intuitiva a una práctica reflexiva. Finalmente, la investigación dejó en claro que el campo es fructífero para muchas reflexiones y transformaciones en la enseñanza de la escritura.

PALABRAS CLAVE: Autonomía. Secuencia didáctica. Redacción. Formación de profesores.

ABSTRACT: This work reflected on teaching-learning of writing in high school from the use of active methodologies, especially problem-solving. The first objective was to analyze the application of active methodologies in writing classes in the 3rd grade of high school at a private school in the interior of São Paulo. Subsequently, based on the reflections generated by the activities, the objective was to produce a didactic sequence aimed at guiding teachers of text production that could contribute to the teaching-learning of written production in basic education. The methodology used was based on action research (FRANCO, 2005), active methodologies (MACEDO, 2005) and construction of didactic sequences (GUIMARÃES; GIORDAN, 2011; ZABALA, 1998). An adaptation of the UN assembly simulation methodology was also used. In general, students had a significant gain in the performance of their argumentative skills, in oral and written production, reflecting on autonomy, empathy, human rights and consensus. However, the activities raised the need to expand the use of such methodologies and didactic situations that encourage autonomy in previous grades, not only at the end of the cycle. As for the construction of the didactic sequence, it proved to be a productive way to share the experience and expand the discussion on active methodologies, in addition to being essential to move from an intuitive practice to a reflective practice. Finally, the research made it clear that the field is fruitful for many reflections and transformations on teaching-learning of writing.

KEYWORDS: Autonomy. Following teaching. Essay. Teacher training.

\section{Introdução}

O trabalho com a disciplina (componente curricular) "Produção de texto" na educação básica, em especial no Ensino Médio, mostra que se trata de uma tarefa que tem seus desafios 
e suas conquistas, logo, é um campo de demandas frutífero para o trabalho de pesquisa. Atualmente, os alunos dessa etapa do ciclo, em especial os terceiranistas, encontram-se envoltos em preocupações com os processos seletivos e com o Exame Nacional do Ensino Médio (ENEM), e a redação sempre é motivo de desgaste, por gerar ansiedade, cobranças, busca por resultados, insegurança quanto à avaliação e às expectativas, imagem que os sujeitos têm do ato de escrever, de si como produtores de texto, entre outros. Do lado dos professores, os desafios também abundam, entre eles, cobrança da equipe gestora por resultados, expectativas dos alunos e dos seus familiares, carga horária da disciplina, material didático à disposição e oportunidades de formação continuada específica. Somam-se a esse cenário as crenças sobre o uso de tecnologias em sala de aula, propostas de metodologias ativas e novos documentos, como a recentemente homologada Base Nacional Comum Curricular (BNCC).

Tendo em vista esse terreno profícuo, propõe-se neste estudo compreender melhor a relação entre a metodologia de resolução de situação-problema aliada ao uso de tecnologia em sala de aula com vistas à proposição de um roteiro de trabalho para aulas de produção de texto no Ensino Médio. Para tanto, foi feito um estudo bibliográfico específico que parte de autores de referência na área e de documentos oficiais (Matriz de Competências do Enem, BNCC, Projeto Político Pedagógico da Escola em que se desenvolve a pesquisa), além de uma pesquisa-ação a partir de uma sequência de aulas de redação em turmas de $3^{\mathrm{a}}$ série do Ensino Médio de um colégio privado no interior de São Paulo.

O objetivo desta pesquisa é, portanto, a partir de um estudo teórico-prático, propor um modelo viável para a sala de aula que esteja alinhado a pressupostos teóricos, metodológicos e documentais e que, principalmente, dê significado ao fazer do professor e do aluno. A meta é refletir sobre condições em que o professor possa experimentar de fato a posição de mediador do processo de aprendizagem (MEIER; GARCIA, 2011) e que o aluno não veja a escrita como um mero cumprimento de tarefa, mas como um gesto significativo na sua formação integral (BRASIL, 2018, p. 14). A preocupação aqui será sempre dupla: de um lado, de quem está em sala de aula e quer, intencionalmente e não mais intuitivamente, criar as condições para uma aprendizagem ativa; de outro, de quem está à frente da orientação de um grupo de professores de linguagens, entre eles, vários de redação, e quer consolidar neste grupo também o ensino de redação com intencionalidade e fundamentação para o trabalho com metodologias ativas. 


\section{Metodologia}

As discussões e a homologação da BNCC trouxeram à tona questões importantes para o cenário da educação brasileira, para além de indicadores estatísticos que já são gerados há certo tempo (Programa Internacional de Avaliação de Alunos-PISA; Sistema de Avaliação da Educação Básica-SAEB; Exame Nacional do Ensino Médio-ENEM). O desafio atual encontra-se na superação de um contexto meramente estatístico e mercadológico em direção a um tratamento qualitativo e reflexivo sobre esse cenário. Assim, o presente trabalho destacará alguns pontos deste estado de coisas em relação a documentos, a teorias e a indicadores que embasarão a pesquisa.

No que tange aos documentos, a Matriz de Competências do Enem ${ }^{4}$ (2009) aponta para a necessidade do trabalho com competências e habilidades a partir de um conjunto de eixos cognitivos comuns a todas as áreas do conhecimento. Entre esses eixos, três dizem respeito a aspectos da produção textual que se quer analisar neste trabalho: III. Enfrentar situações-problema (SP); IV. Construir argumentação (CA); V. Elaborar propostas (EP).

O desenvolvimento de tais eixos está norteado por um conjunto de 09 competências e 30 habilidades específicas da área de Linguagens. Além disso, há uma Cartilha do Participante do Enem que é publicada todos os anos para orientar os alunos em relação à prova, mas é também largamente empregada por sistemas de ensino, materiais didáticos e professores para nortear o trabalho em sala de aula com vistas a atender às expectativas de gestores, mantenedores, sistemas, alunos e familiares em relação ao desempenho quantitativo no Enem. Esse manual traz a Matriz de Referência para a avaliação das redações, organizada por competências específicas, entre as quais destaca-se a quinta: "Elaborar proposta de intervenção para o problema abordado, respeitando os direitos humanos”. A não observância desse critério em sua totalidade (deixar de apresentar a proposta relacionada ao tema da redação e/ou ferir os direitos humanos com a proposta) leva à penalização com nota zero nesta competência.

Sobre essa exigência, a cartilha explica ao participante que o texto que ele produzirá em prova deve, necessariamente, trazer uma proposta de intervenção para o problema abordado por ele. Tal proposta, ainda de acordo com o documento oficial, deve expressar a visão do aluno acerca das possibilidade de solução para a problemática e, ainda, respeitar os

${ }^{4}$ Disponível em: http://download.inep.gov.br/download/enem/matriz_referencia.pdf. Acesso em: 03 mar. 2019. 
direitos humanos, norteando-se por princípios de cidadania, liberdade, solidariedade e diversidade cultural (INEP, 2018, p. 22).

Depreende-se que essa cartilha e, por extensão, as bases teóricas que a fundamentam, vislumbram uma educação que forme cidadãos capazes de refletir sobre situações-problema do cotidiano e de resolvê-las de modo autônomo e autoral ("sua visão, como autor", INEP, 2018, p. 22), mobilizando diversos mecanismos provenientes da sua formação escolar e extra escolar (já que o uso de repertório sociocultural produtivo também consta dos critérios de avaliação - Competência 2). Isso pressupõe um modelo de educação voltado para uma aprendizagem reflexiva e emancipatória que raramente acontece em larga escala, com algumas exceções. Muitas vezes, os alunos não compreendem a importância dessas exigências ou cumprem-nas pela mera obrigação, reproduzindo fórmulas prontas para as propostas de intervenção. Se isso já não fosse, de certo modo, um ponto crítico do estado de coisas, o respeito aos direitos humanos torna-se também causa de dúvida ou de celeuma.

Primeiramente, essa exigência parte de um alinhamento de políticas brasileiras e internacionais relacionadas ao tratamento dos direitos humanos:

- Declaração Universal dos Direitos Humanos (DUDH, 1948);

- Constituição Federal (CF,1988);

- Plano Nacional de Educação em Direitos Humanos (PNEDH, 2006);

- Declaração das Nações Unidas sobre a Educação e Formação em Direitos Humanos (DNUEFDH, 2011);

- Diretrizes Nacionais para a Educação em Direitos Humanos (DNEDH, 2012);

- Programa Mundial de Educação em Direitos Humanos (PMEDH, 2014).

Assim, é de esperar-se que esses documentos e diretrizes sejam de amplo e profundo conhecimento do corpo gestor e do corpo docente e seus pressupostos sejam trabalhados em sala de aula, em todas as disciplinas, já que os alunos construiriam sua autonomia intelectual e, portanto, sua capacidade autoral em todos os espaço-tempos escolares. Contudo, os alunos relatam dificuldade com o manuseio desse saber, já que não faz parte intencionalmente de muitos fazeres pedagógicos, restringindo-se, na melhor das hipóteses, apenas ao currículo oculto. A sociedade, por sua vez, também tem suas dificuldades com o conceito de direitos humanos, fato verificável na simples observação da doxa em torno do tema, materializada por discursos como "direitos humanos para humanos direitos" ou "os direitos humanos servem 
para defender bandidos"5. O nível de não internalização dos direitos humanos pôde ser visto, ainda, no movimento que questionava a validade de se avaliar o respeito a eles na redação do Enem, culminando com uma alteração na aplicação do critério de avaliação ${ }^{6}$.

Uma das finalidades deste artigo consiste exatamente em tornar esse trabalho de autonomia, de autoria e de cidadania perceptível e compreensível aos alunos, de modo que eles reconheçam-se nessa posição, possam comprometer-se com essa visão de aprendizagem e passem a enxergar esse critério do Enem não apenas como método de análise do seu desempenho em uma avaliação de larga escala, mas como objetivo de uma formação integral. Essa que, na visão da BNCC, refere-se à construção intencional de processos educativos que promovam aprendizagens sintonizadas com as necessidades, as possibilidades e os interesses dos estudantes e, também, com os desafios da sociedade contemporânea. (BRASIL, 2018, p. 14)

Desta feita, tendo em vista a educação em direitos humanos "compreendida como processo sistemático e multidimensional que orienta a formação do sujeito de direitos" (PNEDH, 2006, p. 25), chama-se atenção para as dimensões desse processo educativo elencadas no quadro abaixo. A tais dimensões relacionam-se alguns procedimentos metodológicos em sala de aula de produção de texto empregados por esta pesquisa, que se deseja propor ao final deste estudo, como possibilidade de planejamento didático para demais aulas de redação. Essa relação entre dimensões e procedimentos apresenta-se na tabela 01, abaixo:

Tabela 01 - Relação entre dimensões da educação em direitos humanos e procedimentos aplicados na pesquisa

\section{PNEDH (2006)}

a) apreensão de conhecimentos historicamente construídos sobre direitos humanos e a sua relação com os contextos internacional, nacional e local;

b) afirmação de valores, atitudes e práticas sociais que expressem a cultura dos direitos humanos em todos os espaços da sociedade;

\section{Sala de aula}

Estudo da Declaração universal dos direitos humanos (1948) e da importância da Organização das Nações Unidas [ONU], bem como estudo dos artigos $5^{\circ}$ e $6^{\circ}$ da Constituição Federal (1988);

Análise de situações reais, por meio de notícias, reportagnes, propostas de produção escrita, para compreensão da presença e da importância de tais valores;

${ }^{5}$ GRAGNANI, J. O que são direitos humanos e por que há quem acredite que seu propósito é a defesa de 'bandidos'? BBC News Brasil, 2018. Disponível em: https://www.bbc.com/portuguese/brasil-43465988. Acesso em: 03 mar. 2019.

${ }^{6}$ NEVES, C.A.B. Direitos humanos e educação: a polêmica em torno da prova de redação do ENEM 2015 e 2017. Trab. linguist. apl., Campinas, v. 57, n. 2, p. 731-755, 2018. Disponível em: http://www.scielo.br/scielo.php?script=sci_arttext\&pid=S0103-18132018000200731\&lng=pt\&nrm=iso. Acesso em: 03 mar. 2019. 
c) formação de uma consciência cidadã capaz de se fazer presente em níveis cognitivo, social, ético e político;

d) desenvolvimento de processos metodológicos participativos e de construção coletiva, utilizando linguagens e materiais didáticos contextualizados;

e) fortalecimento de práticas individuais e sociais que gerem ações e instrumentos em favor da promoção, da proteção e da defesa dos direitos humanos, bem como da reparação das violações.
Prática do entendimento, da reflexão, do dialogismo e da observância da consciência cidadã por meio da resolução de situações-problema;

Construção de sequência didática e materiais de apoio, juntamente com os próprios alunos participantes, que formarão uma possível sequência didática replicável em demais aulas;

Conscientização dos alunos para que extrapolem as preocupações com seus desempenhos individuais nas redações e reconheçam o impacto em sua formação integral, na sua atuação como cidadãos.

Fonte: Desenvolvido pelos autores.

Além disso, a maneira pela qual a BNCC indica que se alcance a educação integral passa pelas 10 competências gerais, entre as quais destaca-se a $1^{\mathrm{a}}$, a $5^{\mathrm{a}}$ e a $9^{\mathrm{a}}$ para a análise aqui proposta. Tais competências relacionam-se à valorização dos conhecimentos historicamente construídos para compreender a realidade e colaborar para a efetivação de uma sociedade baseada em justiça, democracia e inclusão (1 $1^{\text {a }}$; à compreensão e ao uso de tecnologias de informação e comunicação (TICs) com uma postura crítica, reflexiva e ética para solucionar problemas e ser protagonista na sociedade $\left(5^{\mathrm{a}}\right)$; ao exercício da empatia, do diálogo, da cooperação e da resolução de conflitos respeitando os direitos humanos $\left(9^{\mathrm{a}}\right)$ (BRASIL, 2018, p. 9).

Percebe-se um alinhamento de visões entre esses importantes documentos atuais da educação brasileira (Matriz, BNCC e PNEDH), cujas questões principais são ponto de partida deste artigo. Todavia, a materialização dessa visão de educação deve passar pela reflexão sobre currículo, formação e papel do professor, metodologias e materiais didáticos. Destaquese que essa não é uma preocupação apenas brasileira, haja vista a noção de educação para a cidadania global proposta pela Unesco (2015, p.15), que objetiva criar condições para que alunos possam se engajar e possam assumir posturas ativas, em âmbito local, mas também global, "para enfrentar e resolver desafios globais e, por fim, contribuir de forma proativa para um mundo mais justo, pacífico, tolerante, inclusivo, seguro e sustentável."

Tendo em vista esses pressupostos amplos que justificam o comprometimento com este trabalho, passar-se-á ao seu contexto imediato. O cenário de desenvolvimento desta pesquisa foi um colégio particular filantrópico e confessional que existe há 100 anos no interior do estado de São Paulo. A instituição conta com cerca de 400 alunos matriculados no Ensino Médio (ano letivo 2019), entre eles, aproximadamente 130 na $3^{\text {a }}$ série, portanto, prestes a submeterem-se aos exames seletivos e ao Enem. Entre os alunos, há uma população advinda da classe média-alta e alta e também alunos com direito à gratuidade (carência 
socioeconômica comprovada), todos estudando juntos nas mesmas salas de aula sem qualquer tipo de identificação, diferenciação ou distinção. Isso cria um ambiente interessante de aprendizagem, heterogêneo em relação a expectativas, a projetos de vida e a "capital cultural" (BOURDIEU, 2011, p. 67). A escola adota um material didático apostilado em todo o ciclo, mas há uma liberdade oferecida pelo corpo gestor para que os professores utilizem outros recursos em sala de aula, de acordo com as necessidades.

A matriz curricular da instituição divide a área de linguagens em componentes específicos, com professores diferentes responsabilizando-se por eles: Arte, Educação Física, Língua Espanhola, Língua Inglesa, Língua Portuguesa (gramática), Literatura e Técnicas de Redação (TR). No Ensino Médio, uma professora trabalha TR na $1^{\text {a }}$ série (2 horas-aula semanais) e outra na $2^{\mathrm{a}}$ ( 2 horas-aula semanais) e na $3^{\mathrm{a}}$ série ( 3 horas-aula semanais). A cargahorária de TR da $3^{\text {a }}$ série foi ampliada em 2016 com vistas a intensificar o trabalho prático em sala de aula.

O organograma de gestão da instituição é formado por um diretor geral, um diretor adjunto em cada setor (educação infantil, ensino fundamental anos iniciais, ensino fundamental anos finais e ensino médio), coordenadores pedagógicos por setor e quatro professores especialistas que, além de trabalhar em sala de aula, orientam os demais docentes em relação a questões específicas de cada área de saber (Linguagens, Ciências Humanas, Ciências da Natureza e Matemática). Esses professores especialistas integram a Orientação de Área (OA), criada pelos gestores em 2017. A OA lida diariamente com a formação continuada dos professores, com a reflexão sobre instrumentos e metodologias de avaliação, com a análise de material didático e com o acompanhamento de resultados de avaliações internas e externas. O objetivo da instituição foi criar um espaço interno de formação e autoavaliação do corpo docente, em que haja o fortalecimento de práticas coerentes e adequadas ao contexto específico da própria escola e alinhadas às teorias e aos documentos vigentes. Assim, os resultados apresentados neste artigo inserem-se no âmbito dessas preocupações também, ou seja, fazer uma reflexão que possa estender-se a mais professores, atingindo o trabalho de outros docentes.

O problema que se aborda neste estudo diz respeito ao desejo de tornar mais significativas as aulas de redação para os alunos e para os professores e, para estes, carregada mais de intencionalidade do que de intuitividade, num gesto de saída do currículo oculto. A metodologia escolhida para tornar materializáveis esses objetivos é a de resolução de situações-problema. Trata-se de uma estratégia que visa partir de situações significativas, contextualizadas e reais, sendo que o papel do professor passa a ser o de quem proporciona 
condições, recursos, orientação e instrução aos alunos ao longo do processo de aprendizagem (ARAÚJO, 2014, p. 113). De acordo com Machado (2016), a estratégia de problematização e contextualização na aprendizagem de conceitos vai de encontro à fragmentação da aprendizagem, pois coloca justamente o aluno diante de problemas reais, complexos, os quais o instigarão a dar respostas e soluções também complexas. Macedo (2005) propõe, a respeito da resolução de situação-problemas, que elas sejam pensadas a partir de tarefas para a realização das quais o aluno deve mobilizar seus recursos disponíveis para então tomar decisões (MACEDO, 2005, p. 31).

A escolha por essa estratégia buscou aproveitar todas as possibilidades que ela abriria para potencializar os processos de aprendizagem, já que conjuntamente os grupos de alunos analisaram problemas reais, a partir de papéis pré-determinados, e julgaram entre seus pares a eficácia e a validação de suas intervenções. Porém, além de todo ganho que essa abordagem poderia significar nos processos de aprendizagem, há uma relação interessante entre ela e o desempenho do Brasil em uma análise que a toma também como método. Em 2015, o PISA realizou uma avaliação de Resolução Colaborativa de Problemas (RCP) e, embora nossos documentos oficiais tratem dessa competência há uma década e sejam reforçados por documentos subsequentes, os alunos brasileiros ainda são deficitários nessa atividade.

O PISA define RCP como capacidade de engajamento em um processo no qual dois ou mais sujeitos trabalham conjuntamente para resolver um problema, de modo a compartilhar entendimentos, esforços, conhecimentos e habilidades (Organização para a Cooperação e Desenvolvimento Econômico-OCDE, 2015, p. 3). A matriz do PISA para RCP destaca as seguintes competências: estabelecer e manter entendimento compartilhado; agir de forma apropriada para resolver o problema; estabelecer e manter a organização da equipe. A partir disso, a pergunta norteadora do PISA-RCP foi "Os estudantes de 15 anos de idade estão preparados para trabalhar coletivamente, de forma produtiva?”. A avaliação teve 52 países e economias (32 países-membros da OCDE e 20 países/economias parceiras) participantes. Um dos resultados do relatório aponta que, em média, 28\% dos estudantes dos países da OCDE foram capazes de resolver somente os problemas de baixa complexidade e que exigiam níveis menores de colaboração. No caso dos estudantes brasileiros, esse índice salta para cerca de $60 \%$, chamando a atenção para a dificuldade que nossos alunos têm diante de resolução de problemas e de atividades colaborativas.

Logo, enxergou-se nesse resultado preocupante uma oportunidade de lançar luzes às estratégias de resolução de situação-problema como grandes oportunidades de conseguir que o aluno desenvolvesse múltiplas habilidades, desenvolvesse suas competências cognitivas e 
socioemocionais, construísse seu lugar de fala com autonomia e autoria a partir da internalização "de valores, atitudes e práticas sociais que expressem a cultura dos direitos humanos em todos os espaços da sociedade" (PNEDH). Isso reforça a opção deste artigo pelos modelos de simulação de assembleias da ONU, pois acredita-se que se trata de uma materialização da abordagem por resolução de situação-problema aliada ao trabalho colaborativo, investigativo, dialógico e com base em problemas reais que partiram da observação, análise e escolha dos próprios alunos.

As simulações da Assembleia do Conselho Geral da Organização das Nações Unidas (ONU) acontecem em universidades ${ }^{7}$, em especial onde há a graduação em Relações Internacionais, para que os alunos possam experienciar o fazer diplomático durante discussões de problemas reais que têm sempre finalidade propositiva. No caso desta pesquisa específica, além de formarem grupos de trabalho, escolhendo o país que gostariam de representar, discutirem em grupos que representaram delegações diplomáticas de países, os alunos escolheram os assuntos, pesquisaram sobre eles, formularam temas e os apresentaram em sessões de debates, exercitando, entre outras competências, a escrita de alguns gêneros textuais, como o working paper e a redação dissertativa-argumentativa modelo Enem. A professora-pesquisadora assumiu o papel de mediadora e observadora das estratégias usadas pelos alunos e conduziu a autoavaliação dos grupos de alunos em relação às atividades propostas.

Todo esse processo também incluiu o uso das tecnologias digitais em sala de aula. Moran (2007) chama a atenção para uma visão de escola como "espaço de pesquisa, experimentação, produção, apresentação, debate, síntese”, com possibilidades múltiplas a partir do uso do celular, por exemplo, que sairia de uma situação de condenado por parte dos problemas e iria para a condição de ferramenta de trabalho. Isso ocorreu desde o uso de ferramentas básicas de pesquisa "on line", até o uso de ferramentas de interação, como Mentimeter, e a elaboração coletiva em tempo real de gêneros textuais relacionados às simulações, como o working paper e o próprio texto dissertativo-argumentativo modelo Enem.

O presente trabalho teve natureza aplicada, já que pretendeu produzir conhecimento partindo da revisão teórica, de observações e de uso de metodologia ativa tendo em vista a aplicação desse conhecimento gerado na prática para resolver problemas num contexto

${ }^{7}$ Alguns exemplos: USPMUN: USP Model United Nations, que reúne alunos da USP e da Cásper Líbero; ONU Jr; Universidade Federal Fluminense; AMUN: Americas Model United Nations na Universidade de Brasília; UFUMUN: UFU Model United Nations, na Universidade Federal de Uberlândia; UNSP: United Nations Model of São Paulo na Unesp de Franca; entre outros. 
específico. Tal conhecimento é tanto uma reflexão acerca da prática dos docentes em aulas de redação, bem como um possível modelo metodológico proposto a partir de tal reflexão para que possa ser aplicado em novas situações de aprendizagem em aulas de produção de texto.

A pesquisa desenvolveu-se a partir de uma abordagem qualitativa com objetivo exploratório, por considerar a relação intrínseca e fundante entre o mundo objetivo e os sujeitos envolvidos. Tal relação é opacificada a partir de gestos de interpretação (ORLANDI, 1996) que pretendem compreendê-la e agir sobre ela, tornando explícitos os desafios e os caminhos para melhor lidar com eles. Escolheu-se a pesquisa-ação, levando-se em conta o papel de todos os sujeitos participantes (professor-pesquisador e alunos) pelo fato de ela possibilitar caminhos para analisar, compreender e tentar explicar problemas de um determinado sistema, neste caso as aulas e o trabalho de OA desenvolvidos na escola em questão, para gerar conhecimento prático (LACERDA et al., 2013). Além disso, destaque-se que a pesquisa-ação tem como principais características a. o pesquisador toma a ação; b. envolve dois objetivos: resolver um problema e contribuir para a ciência; c. requer a interação (cooperação) entre pesquisadores e participantes da pesquisa.

Sobretudo, a pesquisa-ação foi a escolhida por permitir que pesquisa e ação possam caminhar lado a lado em prol do objetivo de transformação da situação, envolvendo autocrítica, avaliação de resultados e negociação com os sujeitos nela implicados (MARQUES, 2012, p. 65). Essa abordagem colocaria em horizontalidade professorpesquisador e alunos-participantes e, no caso desta pesquisa, isso pode ser verificado das discussões de procedimentos das atividades que foram propostos, analisados, adaptados e reconfigurados por todos conjuntamente, em especial, pelo grupo de alunos. A ideia é que as regras passem a fazer parte de acordos intersubjetivos e não de acordos impositivos (FRANCO, 2005, p. 492).

Além disso, por objetivar uma transformação não apenas na situação específica de sala de aula com os alunos-participantes, mas também entre os demais professores de redação da instituição, a posteriori, com a discussão da sequência didática, destaca-se o caráter formativo e emancipatório (FRANCO, 2005, p. 485) da abordagem pela pesquisa-ação. Formativo, já que os sujeitos, ao longo da atividade, devem tomar consciência das transformações pelas quais eles próprios passam, bem como o processo em si passa. Emancipatório, tendo em vista que, por intermédio de uma participação consciente nas atividades, os sujeitos poderão ter a oportunidade de deixar para trás imagens negativas sobre si e sobre o ato de escrita, sobre a necessidade de resolver situações-problema eticamente e respeitando os direitos humanos, 
que podem ser, em alguma medida, entraves para uma transformação maior de como se veem como cidadãos autônomos preparados para o exercício da cidadania também fora da escola.

Em resumo, a proposta específica foi, a partir de revisões bibliográficas e do conhecimento prévio que se tem da situação (instituição, alunos, matriz, PPP, contexto), adaptar o modelo de simulação de Assembleias do Conselho Geral da ONU para a sala de aula de TR no Ensino Médio como proposta de resolução coletiva de problema. O produto dessa sequência didática (ZABALA, 1998, p. 18) foi, além dos debates entre os alunos, a escrita de redações no modelo Enem por eles para que percebessem (e este foi o pressuposto número um da presente pesquisa) que o sucesso da produção escrita se dá a partir do exercício da autonomia, do trabalho coletivo e prático, da pesquisa e do engajamento pessoal, da significância que assumem os propósitos dessa escrita para além do resultado quantitativo da prova do Enem. Sendo assim, a pesquisa analisou também trechos de produções de alunos para verificar o engajamento deles com os direitos humanos e o impacto das discussões ocorridas nas assembleias. O produto da pesquisa, além do aporte teórico-metodológico, será a modelização de um conjunto de ações organizadas em uma sequência didática que possa ser aplicado em outras aulas de redação, com outros grupos de alunos e por outros professores.

\section{Resultados e discussão}

Diante dos objetivos desta pesquisa, centrados no desenvolvimento da produção escrita com alunos do ensino médio de forma ativa e na elaboração de uma sequência didática que possa servir de instrumento de formação continuada em serviço para demais professores de redação, esta seção será dividida. Tal procedimento visa organizar os resultados da pesquisa de forma a facilitar a visualização das etapas.

\section{As aulas de redação baseadas nos modelos de simulação da ONU}

Tendo em vista os pressupostos teórico-metodológicos já discutidos, o foco recai agora sobre as ações dos alunos ao longo de todo o processo de investigação. O objetivo primário foi que refletissem sobre alguns temas importantes da atualidade para a escrita de redações no modelo ENEM, mas que essa reflexão partisse de interesses deles e não impostos por uma agenda alheia aos próprios alunos (material didático, vestibulares anteriores ou professor, por exemplo). Desejou-se também que as aulas fossem um espaço de produção, 
ação e não de exercício de fala unilateral do professor na posição de quem oferece, tal como um conferencista, meramente aulas expositivas. Também pretendeu-se que houvesse uma profunda compreensão dos critérios de avaliação da redação do ENEM, em especial no que tange à exigência de uma proposta de intervenção com respeito aos direitos humanos, sobretudo para que ela não se torne uma preocupação exclusivamente ligada ao desempenho quantitativo no referido critério de avaliação, porém uma tomada de posição em relação às demandas globais (Organização das Nações Unidas para a Educação, a Ciência e a CulturaUNESCO, 2015). A seguir, descrevem-se os processos que ocorreram e as reflexões que eles levantaram.

Primeiramente, foi apresentada a proposta das simulações de assembleias da ONU, simplificadas em formato de debates (gênero textual já conhecido pelos alunos de aulas anteriores de redação), como ponto de partida para discussão de temas e mobilização de estratégias argumentativas. Os alunos receberam bem a ideia, porque gostam muito de fazer esse tipo de atividade mais prática, mas, quando souberam que definiriam os assuntos, os temas, os países, o cronograma e um conjunto mínimo de regras, houve certo desconforto. Surgiram falas entre os estudantes apontando que eles não saberiam fazê-lo e que tinham medo de errar. Também não entendiam como a professora deixaria de trazer as propostas prontas e apenas mediaria as atividades. Outros alunos levantaram a hipótese de não estarem "treinando" redação o suficiente, haja vista a necessidade de prepararem-se para os vestibulares, e de que seria necessário que houvesse, além dos debates, aulas expositivas, porque era preciso que a professora também “desse aulas" expositivas.

Compreende-se esse temor de arriscar-se numa postura mais ativa, pois durante anos a escola, enquanto instituição, coloca-os numa posição passiva de quem "ouve" as aulas “dadas" pelos professores. Por mais que tivessem conhecimento prévio sobre argumentação (eles têm aulas de redação dissertativo-argumentativa desde o $8^{\circ}$ ano do ensino fundamental), sobre a redação, sobre debates e temas de atualidade, sentiram-se inseguros e quiseram refugiar-se no conforto proporcionado por aulas tradicionais, essencialmente expositivas, baseadas apenas em aprendizagem mecânica (MOREIRA, 1999, p. 26 e 35), com propostas de intervenção quase decoradas, "soltas", "não articuladas", arbitrárias em relação a modelos cognitivos de compreensão. Essa espécie de rota de fuga faz todo sentido, num sistema em que as escolas (aparentemente abonadas por processos seletivos vestibulares) reforçam que o sucesso na avaliação decorre de estratégias recebidas, decoradas e repetidas a situações hipoteticamente conhecidas porque, justamente, são exaustivamente treinadas. Assim, a primeira constatação da pesquisa foi que era preciso estar sensível a esses temores e passar 
confiança aos alunos para que eles ousassem dar vazão a toda sua potencialidade, mostrar que eles poderiam ter o sucesso esperado se a professora se sentasse ao lado e não permanecesse à frente de pé dizendo o que fazer num sonhado passo a passo, tal qual placebo que asseguraria resultado líquido e certo frente a qualquer situação nova.

De certa forma, esse foi um primeiro desafio, pois, à primeira vista, imaginar-se-ia que oferecer esse "poder" ao adolescente geraria engajamento instantâneo, mas foi preciso mais. Aos poucos, eles perceberam que tinham plenas condições para fazer tudo o que era necessário e que, ao final das rodadas semanais de debate, haveria propostas de redação a partir das quais eles poderiam sistematizar as discussões em textos argumentativos que seriam corrigidos pela professora e devolvidos com apontamentos e sugestões de melhoria. Foi possível, assim, dar início ao trabalho efetivamente. Na primeira semana, os alunos dividiramse em grupos de 4 a 6 membros, sem a interferência da professora em relação aos critérios de formação das equipes, e escolheram qual país gostariam de representar, cientes de que isso implicaria uma atuação ao longo dos debates alinhada às posições políticas, históricas, geográficas, econômicas e ideológicas do país escolhido. Para isso, deveriam usar o que haviam aprendido nas aulas de ciências humanas e suas pesquisas. Para instrumentá-los, a professora enviou-lhes via aplicativo escolar de comunicação oficial "links" contendo vídeos de assembleias da ONU, texto explicativo sobre as assembleias, importância da discussão diplomática de problemas e demais materiais de consulta. A professora também ofereceu uma aula de leitura e discussão sobre a Declaração Universal dos Direitos Humanos para relembrar a relevância desse conjunto de normas para a efetiva concretização das relações de paz e respeito na sociedade. Assim, de posse dessas informações, além da grade com critérios de correção da redação do Enem definindo como deve ser uma proposta de intervenção completa, os alunos tiveram uma aula inteira (45 minutos) para elencar os assuntos que eram de seu interesse. Sem que a professora delimitasse uma regra para isso, poderiam listar quaisquer assuntos que despertassem neles um desejo de aprofundamento e de intervenção (entendida como claro desejo de compreender uma realidade para interferir nela e modificála).

Muitos assuntos surgiram em cada uma das 4 salas de aula de $3^{\text {a }}$ série do ensino médio do colégio onde se deu a pesquisa e eles precisavam ser delimitados para que chegássemos aos assuntos mais relevantes para cada turma. A professora solicitou que todos usassem seus celulares para votarem nos três assuntos mais importantes para cada grupo (delegação) a partir 
da ferramenta Mentimeter $^{8}$, respondendo à pergunta previamente disponibilizada na ferramenta pela professora: "Quais são os 3 assuntos mais importantes atualmente para você?" As respostas foram analisadas e a própria ferramenta gerou, em tempo real, nuvens de palavras (word clouds) que passaram a representar o perfil de interesses de cada sala, que poderiam ser visualizadas por cada aluno no seu "smartphone" e projetadas pela professora no telão da sala, como se pode observar na figura 01, abaixo:

Figura 01 - Word Clouds produzidas pelos alunos em sala de aula
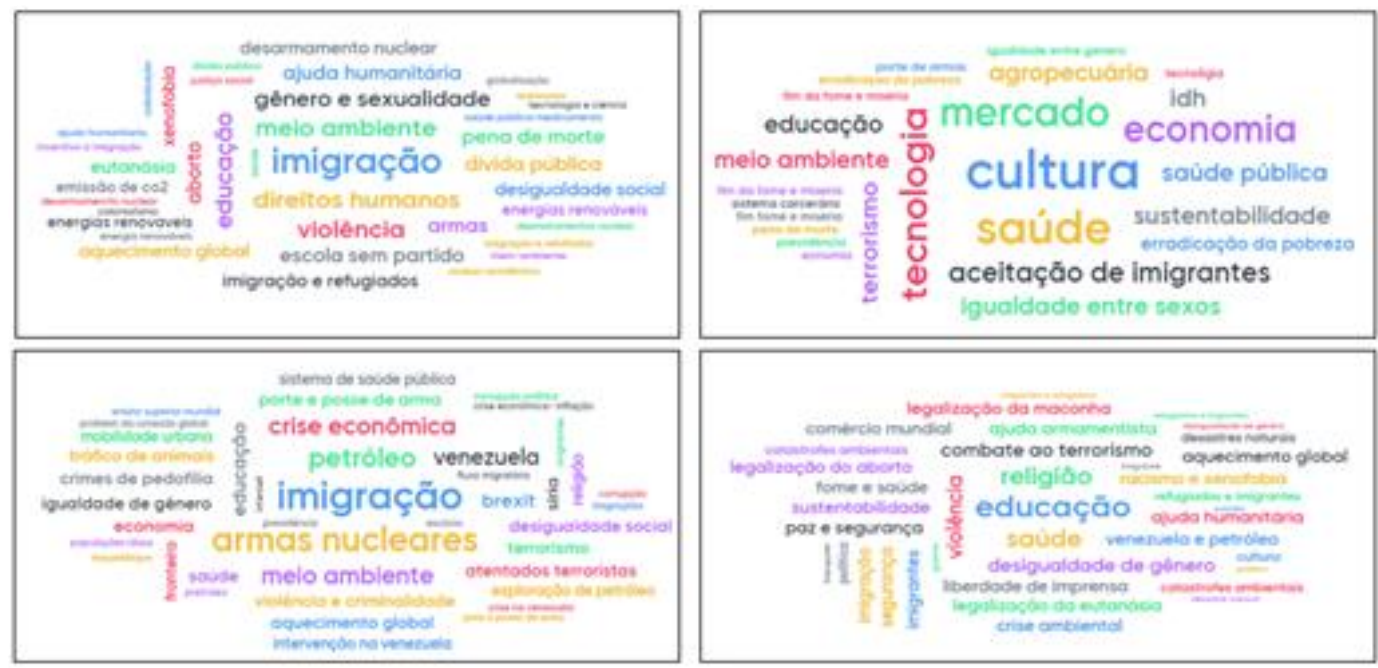

Fonte: Desenvolvido pelos autores.

Os alunos não conheciam a ferramenta e a professora deixou que eles manipulassemna, por ser minimamente intuitiva, mas também por desejar que o celular tivesse um lugar na sala de aula que fosse o de proporcionar uma experiência de aprendizagem. Muitos alunos usaram world clouds em trabalhos anteriores, mas nunca produziram as próprias, faziam "downloads" de imagens prontas e reproduziam-nas. Passou-se mais uma aula analisando a informação fornecida pela nuvem de palavras e percebendo quais assuntos realmente lhes interessavam e, a partir daí, os alunos fizeram recortes temáticos. Vale dizer que, tradicionalmente, nas aulas de redação, os alunos recebem os temas prontos nas propostas, mas dessa vez foi necessário produzi-lo antes que ele se tornasse parte de um debate e de uma proposta de produção. Essa etapa foi trabalhosa e os alunos solicitaram mais o apoio da professora, porém ao final fizeram um bom trabalho de propositura de temas, como é possível

8 "Mentimeter" (2014) é uma ferramenta on line, desenhada pela empresa sueca de mesmo nome, para criar apresentações em público com feedback em tempo real, gerando dados, gráficos, votações instantâneas, nuvens de palavras, entre outros. 
perceber abaixo, seguido de uma votação para decidir qual grupo assumiria a curadoria de cada tema, como se observa na tabela 02, abaixo:

Tabela 02 - temas das simulações definidos por turma e por equipe/ delegação

$3^{\text {a }}$ série A ALEMANHA

"Imigração: barreira física, moral e burocrática" SUÍÇA "Problemas ambientais e desenvolvimento sustentável" NOVA ZELÂNDIA: "A

ilegitimidade da pena de morte" MÉXICO "Falta de estrutura educacional em países subdesenvolvidos" CHINA: "Violência nas periferias de países subdesenvolvidos" CANADÁ "Impasse para a aceitação dos diversos gêneros existentes" BRASIL:

"Intervenção militar é considerada ajuda humanitária ou outros interesses?"

\section{$\mathbf{3}^{\mathbf{a}}$ série $\mathrm{B}$}

JAPÃO: "Como promover o acesso universal à educação para garantir o desenvolvimento da sociedade?" REINO UNIDO: “Qual deve ser a colaboração e cada país na erradicação de doenças reemergentes (HIV, cólera, malária, dengue)?

CANADÁ "Intolerância religiosa é influenciada por governos e favorece crimes de ódio?"

EUA: "Qual deve ser o papel dos estados nacionais no combate à expansão do terrorismo na internet? FRANÇA: "Como a legislação de cada país promover a desmarginalização social?"

HOLANDA: "Para promover a diminuição da violência, devemos priorizar capital na educação ou na segurança pública?"

RÚSSIA: "liberdade de imprensa é uma aliada da democracia?" SUÍÇA: "Como melhorar as tecnologias para erradicar a crise ambiental?"

\section{$3^{\mathbf{a}}$ série $\mathbf{C}$}

REINO UNIDO:

"Causas e consequências da imigração na Europa" MÉXICO: “As armas nucleares são uma necessidade para defesa e soberania nacional?" RÚSSIA: "Petróleo: fonte de guerra ou de renda?"

FRANÇA: "Formulação e reafirmação dos tratados de desenvolvimento sustentável e a fiscalização efetiva dessas ações."

CANADÁ: "Medidas para ajudar países em crise econômica ou em desenvolvimento." EUA: "Venezuela: intervenção militar ou ajuda humanitária?" CHINA: "Investimentos militares para combater o terrorismo."

NORUEGA: "Criação de estratégias e reformas para garantir acesso a saúde mundial" AUSTRÁLIA: "Investimentos em programas de intercâmbio para pesquisa científica"

3a série D
REINO UNIDO:
"Incentivo à cultura e o
reflexo na sociedade"
SUÍÇA: "Saúde pública
e gratuita como direito
básico de todo cidadão"
EUA: "Incentivo a
pequenas empresas e o
benefício para o mercado
interno"
JAPÃO: "O
desenvolvimento
tecnológico na
agricultura e sua
influência no mercado"
DINAMARCA: "O
desenvolvimento da
economia e suas
influências no mercado
interno e externo"
CANADA:
"Acolhimento de
imigrantes: vantagens ou
desvantagens?"
FRANÇA: "Luta contra
o sexismo e promoção de
direitos das mulheres"

Fonte: Desenvolvido pelos autores.

Para encerrar essa fase mais preparatória, destinada à logística do trabalho, era necessário fazer um cronograma. A expectativa da professora era a de que os alunos também conseguissem fazê-lo, considerando a possibilidade de mais um gesto de autonomia. Contudo, depois de algumas tentativas frustradas, a professora precisou fazer o cronograma e levá-lo para que as salas discutissem-no. Uma vez discutido, ele foi aceito pelos grupos, que puderam concentrar-se na definição das regras básicas de condução dos debates (tempos de fala, postura, organização da sala, o que não seria aceito e como compartilhariam os resultados das 
discussões), como pode ser observado abaixo. Foi muito interessante observar que quando o momento das regras chegou, os alunos estavam nitidamente mais seguros que no início do trabalho, pois, apesar de certa dificuldade para produzir esse manual de regras (considerado mais um gênero textual, inserido na tipologia injuntiva, trabalhado ao longo do projeto), porque era necessário chegar a um consenso entre as 4 salas de $3^{\mathrm{a}}$ série do ensino médio, eles se deram conta de que não estavam mais produzindo um gênero porque uma proposta pronta havia sido imposta com uma finalidade meramente avaliativa, como foi comum em aulas de redação do ano anterior, quando aprenderam gêneros e tipologias textuais e treinaram com propostas do vestibular da Universidade de Campinas (Unicamp) e da Universidade Estadual de Maringá (UEM). Agora, a produção envolvia-os diretamente e isso foi significativo. O resultado é o conjunto de regras exposto na tabela 03 que segue abaixo:

Tabela 03 - regras definidas pelas equipes de alunos por meio de consenso

\section{BANCA}

\section{País responsável pelo tema do dia}

FUNÇÕES: conduzir a assembleia: controlando o tempo de cada delegação com cronômetro do celular; observado o cumprimento das regras; apresentando com qualidade e empenho o estudo de caso sobre o tema a ser debatido; promovendo o debate ético e democrático da situação-problema (S-P) e das propostas de intervenção; buscando formar alianças diplomáticas entre as diversas delegações; anotando as propostas e elaborando a escrita do working paper; disponibilizando a versão final do paper para a assembleia em meio digital (grupo de Whatsapp criado para a socialização dos debates com todos os alunos)

\section{FUNÇÕES e REGRAS DELEGAÇÕES \\ Demais países presentes}

FUNÇÕES: observar as regras para um debate sadio, ético e diplomático das S-P colocadas por cada banca; respeitar, ainda que discorde, das propostas e posicionamentos das demais delegações; respeitar o tempo de fala; respeitar a ordem de pronunciamento estabelecida pela banca; colaborar nos debates com dados, informações e propostas tendo, para isso, preparado-se previamente para cada assembleia de acordo com o cronograma previamente estabelecido por cada sala.

\section{PROFESSORA}

FUNÇÕES: propiciar os materiais, o espaço e a organização mínima para que as assembleias ocorram de maneira sadia, ética e diplomática; garantir o exercício pleno da autonomia dos alunos dentro do limite de regras de conduta do Colégio; apoiar, incentivar e dar suporte para a banca e para as delegações; mediar sem interferir-se nas escolhas de países, temas e situaçõesproblema, nos debates e na condução das discussões.

As delegações:

1. devem estudar a S-P previamente;

2. podem usar celular, tablets, anotações, internet durante as assembleias para construir

REGRAS suas propostas e argumentações;

3. devem observar normas de conduta e comportamento (decoro) adequadas a uma situação de debate diplomático (postura, comprometimento, respeito, conversas paralelas, pontualidade, linguagem, vestimenta);

4. devem comportar-se de modo coerente com o país escolhido, em termos de política interna, externa, economia, geografia, história, princípios, ideologia, etc.;

5. devem manifestar concordância com as propostas apresentadas por uma outra delegação com um gesto de mãos (palmas na linguagem de surdos-mudos).

6. devem contribuir efetivamente para a produção do working paper da banca, avaliando as propostas, julgando-as e explicitando detalhadamente o modo de execução de cada uma.

Fonte: Desenvolvido pelos autores. 
Os debates poderiam começar. Entretanto, os alunos sugeriram produzir crachás com a identificação de cada delegação e, embora isso implicasse mais tempo de preparação, preocupando a professora e o cumprimento de um cronograma da própria escola e da pesquisa em questão, a ideia foi bem acolhida pelo grupo de alunos que decidiu que os que tivessem mais habilidade com desenho e ferramentas para isso se encarregassem. Então, eles fizeram uma votação com as três propostas gráficas de crachá apresentadas e escolheram uma que a sala de cópias da escola produziu. Esse momento demonstra, mais uma vez, que apesar de um receio geral no início, quando recebiam o espaço para a autoria ele poderia ser bem ocupado pelos alunos. Mas, marca também que não é tão fácil o professor estar disponível a não ter o controle sobre todas as partes do processo de um trabalho, pois a professora sentiu que deveria recuar do cronograma de pesquisa originalmente proposto em favor da disponibilidade de engajamento dos alunos. Esses desconfortos bilaterais (professor e aluno) precisam ser divididos entre os grupos de professores como uma maneira de fortalecerem-se diante de práticas metodológicas ativas e descentralizadas, para que todos percebam que é possível. Percebam também a possibilidade de ocupar o espaço das imprevisibildiades de modo produtivo.

Ao final desta etapa mais logística, os alunos teriam três semanas para prepararem-se para o início das rodadas de debates. Eles fizeram isso em casa ou na escola, virtualmente ou em reuniões entre eles, sem a presença da professora. Puderam solicitar a ajuda de professores de história e de geografia do colégio e consultar todo o material que desejassem. No entanto, mais um desafio colocou-se ao projeto: os alunos reuniram-se para dizer à professora que agora estavam novamente inseguros porque lhes parecia muito difícil levar a cabo aquela tarefa de conduzirem a discussão e comportarem-se como os países escolhidos. Antes que o temor crescesse e abalasse a confiança dos alunos, a professora fez uma proposta: com base na noção de homologia de processos (SCHÖN, 1992), ela simularia fazer parte do grupo de alunos e faria uma discussão praticando todas as regras e combinados prévios do grupo. Fariam parte do grupo da professora os alunos que integravam o primeiro grupo a ser a banca de condução da primeira rodada de debate. Assim foi feito e não houve a explicação, via aula expositiva, de como dar-se-iam as simulações das assembleias. Houve uma simulação e os alunos questionaram a professora como se ela fosse um deles. Foi um momento interessante da pesquisa, pois houve uma certa horizontalidade, não só porque todos estavam em círculo, mas porque a professora e eles faziam as mesmas atividades, a partir das regras comuns definidas por eles, não impostas. Embora estar na posição de quem fala faça parte da rotina 
docente, estar falando naquela posição foi diferente, uma vez que estavam todos sujeitos às mesmas prerrogativas e isso contribuiu, em alguma medida, para a confiança dos alunos.

Para pensar as etapas das simulações (preparação - debate - conclusão) a partir da aprendizagem baseada na resolução de problemas (Problem Based Learning-PBL), propôs-se recorrer ao Arco de Maguerez (BERBEL E SÁNCHEZ GAMBOA, 2011, p. 269), conforme figura 02 , abaixo.

Figura 02 - Arco de Maguerez

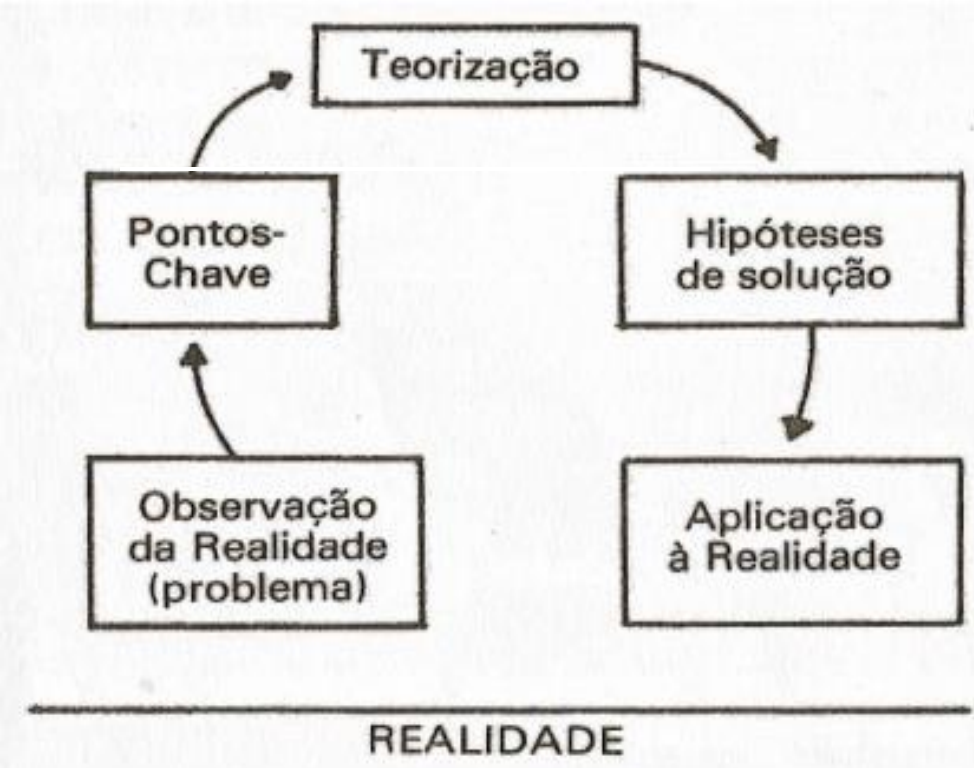

Fonte: BERBEL; SÁNCHEZ GAMBOA (2011, p. 269).

1. observação da realidade: consistiu na observação do contexto contemporâneo, pelos próprios alunos, para que definissem assuntos (mais gerais), temas (recortes dos assuntos) e uma ou mais situações-problemas (teses) que representassem situações reais;

2. pontos-chave (ou síntese): envolveu a identificação dos pontos centrais do problema a ser resolvido, quais seriam os possíveis conteúdos teóricos relacionados que deviam ser compreendidos para que fosse possível a solução do problema e as variáveis envolvidas. Nesta etapa, os alunos precisaram definir o escopo dos debates: tal problema seria discutido tendo em vista o contexto de qual país e como cada delegação poderia contribuir com a compreensão da situação-problema;

3. teorização: concentrou-se no estudo teórico dos conceitos que devem ser compreendidos. O aluno compreenderá o problema não só baseado pelas suas experiências ou pelas situações, mas pelos princípios teóricos que o explicam. Nesta etapa, os alunos recorreram a pesquisas, a aulas de outras disciplinas e a demais professores, além do estudo de caso introdutório a ser apresentado pela delegação responsável da rodada. Alguns conceitos como imigração, doenças endêmicas, intolerância, sexismo eles já conheciam das aulas específicas, todavia agora precisariam transferir esses conceitos a uma realidade problemática nova escolhida por eles; 
4. hipóteses de solução: atividade de exercício da criatividade dos alunos para criar possibilidades de solução para o problema analisado, fundamentando as propostas no estudo teórico realizado anteriormente e nas regras básicas de uma proposta de intervenção de modelo ENEM (agente responsável pela ação + ação interventiva concreta + modo de execução + efeitos pretendidos com a ação + detalhamento);

5. aplicação à realidade: consistiu na ação principal das discussões, pois pressupõe a verificação das hipóteses de solução criadas, que deveriam ser votadas pelas delegações a partir da viabilidade, mas também do conjunto mínimo de valores de cada delegação. Neste momento, inclusive, nas salas em que havia os países com poder de veto no Conselho de Segurança Geral da ONU (EUA, França, Reino Unido, Rússia, China), eles poderiam barrar algumas hipóteses de solução e a discussão deveria recomeçar. Assim, ao recomeçar a discussão, deveriam, diplomaticamente e por meio de argumentos, buscar o consenso. Ao fim, para propostas inviáveis, os alunos poderiam repensar o problema, criando novas hipóteses, a fim de solucioná-lo. Para soluções viáveis, deveriam registrá-las para que fossem comunicadas às outras salas, já que parte do objetivo das aulas era compreender a maior quantidade possível de temas atuais e isso seria facilitado pela socialização dos resultados dos debates entre as salas.

A título de exemplo do trabalho de definição de escopo que cada equipe entregava previamente (7 dias antes do debate) ao restante da sala via grupos de Whatsapp, seguem dois casos, conforme a tabela 04:

Tabela 04 - exemplos de definições de escopo de debate feitas pelas equipes/ delegações

\section{Simulação ONU - 03/09/2019 - França}

Tema: Luta contra o sexismo e promoção de direitos das mulheres

Escopo: " O descaso do governo brasileiro em relação ao turismo sexual e suas consequências para a imagem e os direitos da mulher brasileira." [SITUAÇÃO/PROBLEMA]

\section{Objetivos:}

a) Identidicar o conceito de turismo sexual.

b) Entender o por quê do Brasil estar no centro da discussão.

c) Relacionar o conceito de turismo sexual com a danificação da imagem da mulher no Brasil.

d) Relacionar as atitudes do governo brasileiro atual com a problemática.

e) Propor uma proposta de interverção baseada nas políticas do país que sua delegação representa.

\section{$\underline{\text { Textos de apoio: }}$}

https://www.brasildefato.com.br/2016/05/03/docume ntario-relata-turismo-sexual-no-brasil/ https://www.direitonet.com.br/artigos/exibir/3500/Tu rismo-sexual-um-problema-que-se-agravadiariamente

https://www.google.com/amp/s/luizasahd.blogosfera. uol.com.br/uol_amp/2019/04/26/ao-que-tudo-indicabolsonaro-apoia-ou-desconhece-turismo-sexual-nobrasil/

\section{Simulação ONU - 28/08/2019 - EUA}

Tema: O desenvolvimento da economia e seus impactos no mercado externo e interno

Escopo: A desistência do Brasil do Tratamento Especial e Diferenciado (TED) da OMC: vantagem ou desvantagem para a economia do país?

- Como outros países emergentes podem ser afetados se também abrirem mão do TED? [REFLEXÃO]

Textos de apoio:

https://g1.globo.com/economia/noticia/2019/0 3/20/sem-tratamento-especial-na-omc-brasilperde-poder-de-barganha-mas-ganha-statusde-pais-desenvolvido-entenda.ghtml http://legis.senado.leg.br/sdleggetter/documento/download/3dda9ef4-be494f57-8ff8-4af7e2738d52 http://www.itamaraty.gov.br/pt-BR/notas-aimprensa/20242-tratamento-especial-ediferenciado-e-a-omc https://economia.estadao.com.br/blogs/mosaic o-de-economia/o-tratamento-especial-nocomercio-beneficia-os-paises-emdesenvolvimento/ http://repositorio.ufba.br/ri/handle/ri/10938 
https://www1.folha.uol.com.br/seminariosfolha/2019

/05/turismo-sexual-e-controlado-por-mafias-e-fica-amargem-de-estatisticas.shtml

https://www.google.com/amp/s/oglobo.globo.com/br asil/levantamento-mostra-que-mais-de-3-mil-sites-

vendem-turismo-sexual-no-brasil-

$16581696 \% 3$ fversao $=$ amp

https://www.redebrasilatual.com.br/cidadania/2019/0

4/sem-incentivo-de-bolsonaro-estados-e-coletivos-

fazem-campanha-contra-turismo-sexual/

Fonte: Desenvolvido pelos autores.

Para o registro das discussões e das propostas de intervenção, os alunos usaram o gênero textual working paper, que se refere a uma escrita em processo, pois se dá ao longo da discussão. Para isso, poderiam usar papel, tablet, celular ou computador. Conjuntamente, os alunos e a professora desenvolveram um modelo de working paper (conforme Tabela 05, abaixo), pois esse tipo de texto também é usado nas simulações oficiais que acontecem nas universidades; no entanto, foram feitas adaptações de acordo com o que os alunos julgaram importante apresentar como resultado concreto ao final de cada simulação. Cada simulação gerou um documento desse tipo, que foi compartilhado pela professora com todos os alunos das quatro salas de $3^{\mathrm{a}}$ série para que as discussões fossem amplamente socializadas.

Tabela 05 - modelo de working paper produzido pelas equipes/delegações

\section{WORKING PAPER}

(formulário a ser preenchido pela banca e entregue após a conclusão da assembleia à professora) DELEGAÇÃO PRESIDENTE DA BANCA E SEUS MEMBROS:

Nome do país e dos alunos que o representam. É a delegação que presidirá a banca e organizará a discussão DATA DA ASSEMBLEIA E SITUAÇÃO-PROBLEMA (S-P):

Data em que houve a reunião e a $S$ - $P$ que a delegação escolheu previamente. CONTEXTUALIZAÇÃO DA S-P (RESUMO DO ESTUDO DE CASO):

A banca deve apresentar detalhadamente um estudo de caso para contextualizar a S-P: escopo, causas, consequências, dados com fontes, conceitos se necessário, hipóteses de solução levantadas pela banca a serem discutidas com as demais delegações. Cobrar das demais delegações que se posicionem sobre a tese, sobre a $S$ $P$, sobre as propostas levantadas pela banca e cobrar propostas e observações das delegações sobre a $S$ - $P$ da banca.

\begin{tabular}{lr}
\multicolumn{2}{c}{ PROPOSTAS APRESENTADAS PELAS DELEGAÇÕES PRESENTES: } \\
ACEITAS E RECURSOS PARA VIABILIZAÇÃO & RECUSADAS E JUSTIFICATIVAS \\
Elencar as propostas que foram discutidas e aceitas & Elencar as propostas que foram rejeitadas pela \\
pela assembleia e explicar o modo de execução & assembleia e justificar porque foram refutadas
\end{tabular}

Fonte: Desenvolvido pelos autores.

Os debates tiveram início e o cronograma de simulações foi cumprido. Nos primeiros, não houve resistências de participação, mas houve um pouco de inibição, preocupação com "estar fazendo do jeito certo", muitos movimentos de olhares procurando pelo consentimento da professora e reservas quanto a fazerem, às vezes, o papel de quem organiza e coloca em 
ordem grupos diferentes querendo falar ao mesmo tempo ou mesmo quando o debate entre ideias divergentes deveria ser conduzido. Aos poucos, os alunos foram ficando mais confortáveis nessa posição de autonomia e foram compreendendo o que significava representar, com o mínimo de coerência, ideologias e posturas de países diferentes e, por vezes, conflitantes até com os seus conjuntos de valores.

É preciso destacar que, no geral, os alunos tiveram uma postuta bastante colaborativa entre si, ajudando-se e socializando as propostas a que têm chegado entre os demais grupos de alunos. Num paralelo com as informações levantadas pelo relatório PISA-RCP, foi possível ir percebendo a cada rodada de simulação uma adesão maior à colaboração entre as delegações e não uma relação de competição. Os alunos de uma determinada sala, por exemplo, atuaram na primeira rodada de debates muito empenhados em competir entre si, agindo como se suas falas e propostas devessem "arrasar" o "oponente", num duelo de fatos e de argumentos. Na aula seguinte, fazendo a avaliação da atividade, os alunos foram se dando conta de que o clima do debate não foi favorável a acordos diplomáticos, por exemplo, porque o conjunto de valores de cada grupo sobrepôs-se ao da assembleia. A professora fez uma intervenção a fim de retomar os propósitos das assembleias da ONU e a importância do consenso.

Na rodada seguinte, esse clima competitivo foi se diluindo, aos poucos, já que o perfil dessa sala é mais competitivo, mas nas simulações seguintes já houve alianças, como aconteceu mais nas demais salas. As delegações passaram de uma fase inicial de muitos confrontos de ideias para uma fase de alianças, unindo-se em favor da resolução da situaçãoproblema do dia, de modo que cada país possa oferecer o que teria de melhor em termos de recursos materiais e humanos em função daquele problema específico. Momentos de tensão aconteceram, inevitavelmente, por conta dos temas e das delegações, porém eles enriqueceram as simulações.

Em uma simulação em uma determinada sala, estavam presentes as delegações do Reino Unido, da Rússia, da França, dos EUA e do Canadá, entre outras, debatendo a legitimidade do uso de armas nucleares. Cada delegação começou a expor seu posicionamento a respeito e depois passaram a acusar-se por violações de tratados internacionais sobre enriquecimento de urânio, comércio e armazenamento de armas nucleares. As delegações começaram a alinhar-se em dois blocos, em torno da Rússia e dos EUA, e houve uma forte polarização do tema. Foi possível sentir a alteração no clima das discussões ao longo daqueles 45 minutos, a ponto de um membro da banca que era dirigida pelo México intervir e questionar os EUA e a Rússia sobre aparentes ameaças bilaterais. Desta simulação, destacariam-se vários elementos para a pesquisa aqui proposta (estratégias de validação de 
argumentos e de convencimento, ampla pesquisa sobre um tema tão específico, esforço para ocupar a posição de fala de países com postura tão claras sobre o tema e, às vezes, bastante conflitantes com as posturas dos alunos, entre outros). Mas é necessário enfocar duas com mais atenção.

Primeiramente, uma das imagens pré-concebidas pelos alunos sobre seu desempenho e sobre a redação era que eles não eram bons o suficiente, seus textos não seriam bem avaliados, se a professora não continuasse com as aulas expositivas eles não aprenderiam apenas com debates. Esses preconceitos precisavam ser transformados de dentro para fora, a partir de uma ação que fosse emancipatória (FRANCO, 2005), para que eles compreendessem que tinham competências e habilidades desenvolvidas para isso e que poderiam exercer a autonomia. Esse debate sobre armas nucleares, assim como outros, mostrou-lhes que eles eram capazes de muito. $\mathrm{O}$ que eles conseguiram construir naquela semana superou, em algumas situações, ao que conseguiam produzir quando apenas recebiam uma proposta de redação pronta, levada pela professora, com um prazo determinado de entrega. Alunos que jamais participaram nas aulas tradicionais demonstraram protagonismo e postura de excelência, colocando-se nas discussões, defendendo seus pontos de vista, em especial em situações de completa imprevisibilidade, porque havia muitas perguntas de uma delegação para outra sem que fossem programadas e todas deveriam ser respondidas.

Ademais, mesmo que algumas equipes não tenham feito tantas referências à Declaração Universal do Direitos Humanos como a professora esperava, muitos conceitos deste documento internacional estavam norteando as discussões e operando pequenas reflexões. Dias após o debate sobre armas nucleares, um membro da delegação dos EUA, conversando com a professora sobre as simulações, disse se sentir muito excitado em todas as discussões e muito provocado. Comentou que quando estava debatendo avidamente com a Rússia e seus aliados, só pensava nas estratégias que usaria para impor-se, mas depois da simulação começou a pensar que aquilo tudo de fato ocorria nas Assembleias da ONU, mas com países de verdade, discutindo coisas que poderiam mudar de verdade a vida de milhões de pessoas e que muitos não faziam a menor ideia disso. E que ao fim, todos eram como ela, apenas uma pessoa no mundo real que não anda de carros blindados, nem tem bunkers em casa, mas que está sujeita a decisões alheias a ela. Esse tipo de tomada de consciência de si, de seu papel e da importância da empatia dificilmente aconteceriam numa produção escrita mecânica, centrada na reprodução de um modelo, com uma proposta de intervenção enformada, fruto de uma aula completamente tradicional. 
Outro fato relevante da pesquisa é que, em um dado momento do cronograma, alguns alunos manifestaram preocupação em relação ao cumprimento do "conteúdo" de redação, especificamente, se estavam aprendendo aquilo que seria necessário para as provas dos vestibulares. Essa reação, de certa forma, já era esperada pela professora, que interviu apontando para tudo o que haviam produzido e aprendido até aquele momento e para a importância das produções escritas como materializações de todo o processo, ao mesmo tempo que eram também o instrumento de avaliação do vestibular. Mas o conforto só veio com a observação de notas de redações, como provas concretas tradicionais, habituais de que tudo caminhava na direção esperada por eles. Esse fato foi visto pela professora como um traço persistente da visão tradicional de avaliação por conceitos, embora não passível de invalidar o processo de aprendizagem tal como se propõe a pensar neste estudo. Talvez estejamos num processo de transição, no qual essas notas, provas concretas de desempenho, possam servir como validação de uma metodologia ativa para que ela ganhe a confiança dos alunos e, de certa forma, de familiares e gestores, que ainda precisam visualizar o resultado do desempenho dos alunos no boletim. Assim, observadas as médias das notas de redação modelo ENEM anteriores às simulações em relação às posteiores, é possível notar um salto quantitativo que reflete a qualidade das discussões, conforme a tabela 06, abaixo:

Tabela 06 - média comparativa do desempenho dos alunos em dois critérios da redação

\begin{tabular}{lcccccc} 
& \multicolumn{2}{l}{ Média antes das simulações } & \multicolumn{3}{c}{ Média após as simulações } \\
& Colégio & Rede & Colégio & Rede \\
Critério III & 124 & & 125 & & 146 & 137 \\
Critério IV & 150 & & 118 & & 164 & 114
\end{tabular}

Fonte: Desenvolvido pelos autores

Cada um dos cinco critérios na grade de correção do ENEM vale 200 pontos, escalonados de 40 em 40, totalizando uma nota máxima de 1000 pontos. O critério I avalia o desempenho em norma culta; o II, o cumprimento do gênero textual, o atendimento ao tema e o uso de repertório; o III, a qualidade da argumentação; o IV, o uso de estratégias de coesão textual; e o V avalia a proposta de intervenção. A instituição onde a pesquisa ocorreu aplica periodicamente simulados de ENEM, corrigidos por técnicos externos ao colégio, cujos resultados são comparáveis aos demais alunos que fazem o mesmo simulado na rede de instituições que usam aquele simulado.

Logo, é perceptível um incremento nas notas que pode refletir, em parte, o empenho dedicado às simulações e as transformações que resultaram delas. A desenvoltura, a postura, a 
autoconfiança, a capacidade moderadora e colaborativa dos alunos, ao lado das suas habilidades argumentativas e maior domínio de alguns temas, parece algo bastante perceptível nas observações, nos acompanhamentos e nos textos escritos. Porém, a ideia da pesquisa é que as notas não sejam a finalidade em si das atividades, mas apenas uma parte do processo. Acredita-se que, frente aos demais professores de redação da instituição, haja também uma expectativa acerca do resultado quantitativo da metodologia, e o desafio consiste em valorizar, além desse, o qualitativo também.

\section{Proposta de sequência didática}

Quanto ao objetivo de produzir elementos para uma proposta metodológica de sequência didática (SD) para aulas de redação, ela foi escrita e organizada e, na semana de planejamento da instituição (janeiro de 2020), poderá ser oferecida uma oficina às professoras de redação para que conheçam e discutam a metodologia ativa a partir da proposta fruto deste trabalho de pesquisa e possam refletir e propor novas sequências didáticas baseadas na aprendizagem por resolução de problema.

Partindo de Zabala (1998, p.18), a sequência didática foi pensada a partir da estruturação de uma série de atividades ordenadas e articuladas para se alcançar um objetivo pedagógico, no caso, a aprendizagem da produção escrita de textos dissertativoargumentativos de forma ativa. Tal conjunto de atividades deve apresentar um início e um fim e deve ser de conhecimento tanto do professor quanto dos alunos. Tal perspectiva das sequências didáticas alia-se, nesta pesquisa, à sua potencialidade de diluição de tensões provocadas por situações de ensino-aprendizagem descontextualizadas (GUIMARÃES; GIORDAN, 2011), desconectadas com a realidade da escola e do mundo. Também se compreende a elaboração e a reflexão sobre as sequências didáticas como possibilidade de renovação de práticas do processo formativo (GUIMARÃES; GIORDAN, 2011).

É uma ferramenta capaz de romper com ciclos de reprodução de um currículo e de um conjunto de práticas ocultas, pois seu fazer demanda do professor uma reflexão sobre a sua prática e sobre seus modos de operacionalizar conceitos, procedimentos e abordagens, visando situações reais dos seus alunos reais, com os quais divide a sala de aula semanalmente, e não com espectros de alunos ideais ou invisíveis que não pertencem àquela situação de aprendizagem. Permitem ao professor enxergar-se no seu fazer ao planejá-lo. 
Zabala (1998, p. 63-64) alerta para a necessidade de se refletir sobre as sequências didáticas a partir de duas questões fundamentais: de um lado, seu potencial de dar condições para o maior grau de significância das aprendizagens para os alunos envolvidos, de outro, seu potencial de permitir que os professores se atentem à diversidade dentro da sala de aula. Para isso, o autor sugere alguns questionamentos norteadores da validação das atividades de uma sequência didática. Resumidamente, deve-se questionar se: elas são capazes de permitir o levantamento de conhecimentos prévios; apresentam o conteúdo de forma significativa e funcional; são adequadas ao nível dos alunos; oferecem desafios atingíveis; provocam conflito cognitivo e atividade mental; despertam atitude favorável, motivadora; despertam a autoestima e o autoconceito do aluno; levam o aluno a desenvolver habilidades ligadas ao aprender a aprender.

Giordan e Guimarães (2011) apresentam didaticamente os elementos essenciais de uma sequência didática, que são úteis para o ordenamento dos procedimentos e foram usados neste trabalho para organizar a proposta que segue expressa na tabela 07.

Tabela 07 - Sequência Didática elaborada a partir da experiência e das reflexões da presente pesquisa (continua)

TÍTULO (refletir o conteúdo e as intenções formativas)

PÚBLICO-ALVO (condições às quais será submetido)

PROBLEMATIZ AÇÃO (agente que sustenta a relação sistêmica da SD)

OBJETIVO GERAL

(passível de ser atingido)
Ensino de produção de texto dissertativo-argumentativo a partir de metodologias ativas e resolução de situação-problema

$9^{\circ}$ ano do ensino fundamental a $3^{\mathrm{a}}$ série do ensino médio

Resolução colaborativa de situações-problemas reais escolhidas a partir de trabalho em equipe e discutidas no formato de simulações da ONU

Desenvolver nos alunos habilidades de resolução de problemas a partir de uma postura ética, cidadã, responsável, autônoma, empática e colaborativa
OBJETIVOS

ESPECÍFICOS

(metas do processo

de ensino-

aprendizagem

passíveis de serem atingidas mediante desenvolvimento
Desenvolver a habilidade de:

a. observar a realidade e destacar assuntos relevantes dentro do seu contexto, transformando-os em temas e em problemas;

b. analisar uma situação-problema, observando suas causas e suas consequências;

c. construir hipóteses de resolução da situação-problema e testá-las discutindo-as com seus pares;

d. organizar uma argumentação coerente capaz de defender seu ponto de vista sobre o tema, o problema, suas causas e consequência e sua hipótese de solução;

e. analisar o contexto mais amplo e compreender as relações entre países e a sua atuação para a construção da paz e do bem-estar mundial;

f. observar e respeitar a diversidade de culturas, posicionamentos e opiniões; 
da situação de ensino proposta)

\section{CONTEÚDOS}

(refletir os

objetivos, podem ser disciplinares ou interdisciplinares) g. compreender os conceitos de direitos humanos, igualdade e dignidade presentes da Declaração Universal dos Direitos Humanos e na Constituição brasileira;

h. debater diplomaticamente e construir o consenso;

i. comunicar decisões consensuais a grupos maiores;

j. transpor para o gênero textual "redação escolar modelo ENEM" as discussões.

a. estratégias argumentativas (argumentos de autoridade, relações de causa-consequência, contra-argumentação, hipóteses e projeções futuras);

b. elementos essenciais de uma proposta de intervenção (agente, ação, modo de execução, efeito pretendido e detalhamentos);

c. conceitos de direitos humanos, dignidade, igualdade;

d. conceitos de debate, polêmica, dissenso, consenso;

e. importância da ONU e da atuação dos membros permanentes do conselho de segurança; f. contexto social, político, histórico e econômico dos países escolhidos.

Tabela 7: Sequência Didática elaborada a partir da experiência e das reflexões da presente pesquisa (conclusão)

2 aulas: discutir a importância da ONU, da Declaração Universal dos Direitos Humanos e sua relação com a Constituição brasileira;

2 aulas: propor o trabalho, deixar que os alunos formem as equipes, escolham os países que representarão nas simulações, escolham os assuntos, recortem os temas e formulem as teses (situações-problemas - S-P);

1 aula: as equipes devem decidir, formular e votar as regras das simulações;

DINÂMICAS 1 aula: cada equipe terá 1 aula para dirigir a simulação e pôr em debate a sua

S-P (calcular de acordo com a quantidade de equipes);

2 aulas: autoavaliação das simulações e socialização dos resultados.

Postura do professor: "mansa na escuta e forte nas decisões" (Franco, 2005, p.493) observar ao máximo, interferir minimamente para que os alunos tenham espaços de autonomia e tomadas de decisão; intervir apenas quando estritamente necessário; dar devolutivas pontuais às equipes para colaborar com o desenvolvimento das atividades; ajustar-se às imprevisibilidades, recebendo-as como parte do processo de construção do conhecimento por mediação e por metodologias ativas.

AVALIAÇÃO

(relacionada diretamente ao que se pretende ensinar)

REFERÊNCIA

BIBLIOGRÁFIC

A

(materiais usados no

desenvolvimento das aulas)

BIBLIOGRAFIA

UTILIZADA

(material usado na produção da sequência didática e que servirá de apoio ao professor)
Autoavaliações orais entre as simulações e/ou ao final do ciclo de simulações, a depender das necessidades do grupo de alunos;

Produções escritas a partir dos temas trabalhados nas simulações, corrigidas segundo critérios previamente conhecidos pelos alunos. No caso do ensino médio, usar os parâmetros da Matriz do INEP para a redação do ENEM; no caso do $9^{\circ}$ ano do ensino fundamental, adaptar os parâmetros de correção ao estágio de desenvolvimento dos alunos. INEP. (2018) Redação no Enem 2018 - Cartilha do participante. Brasília: INEP,

http://download.inep.gov.br/educacao_basica/enem/guia_participante/2018/manual_de_red acao_do_enem_2018.pdf Acesso em: 02/03/2019.

BRASIL. (1988). Constituição da República Federativa do Brasil: promulgada em 5 de outubro de 1988.

Assembleia Geral da ONU. (1948). Declaração Universal dos Direitos Humanos. Paris.

Retirado de http://www.un.org/en/universal-declaration-human-rights/

ARAÚJO, U.F. (2014) Temas transversais, pedagogia de projetos e mudanças na educação. São Paulo: Summus.

BERBEL, N. A. N., \& SÁNCHEZ GAMBOA, S. A. (2011). A metodologia da problematização com o Arco de Maguerez: uma perspectiva teórica e epistemológica. Filosofia E Educação, 3(2), 264-287. https://doi.org/10.20396/rfe.v3i2.8635462. Acesso em 16/07/2019

MACEDO, L. de. (2005) A situação-problema como avaliação e como aprendizagem. in MORAES, J.S. (Org.) Exame Nacional do Ensino Médio (ENEM) - Fundamentação Teórico-Metodológica. Brasília: O Instituto (INEP / MEC), p. 29 - 36.

Fonte: Desenvolvido pelos autores.

A proposta é, da posição de orientador de área, promover encontros formativos com os demais professores de redação da instituição para debater o uso de metodologias ativas no 
ensino-aprendizagem de redação, bem como a utilização de adaptações do modelo de simulação da ONU como uma dinâmica pedagógica. Esse trabalho visa, assim, encorajar os demais docentes a moverem-se de práticas pedagógicas tradicionais em direção a práticas mais ativas e reflexivas, que façam com que o professor se aproprie conscientemente, intencionalmente de seu fazer, para que ele seja mais significativo para o profissional e para o aluno.

Resta apontar um elemento para um horizonte de reflexão: a avaliação das competências socioemocionais. De acordo com a BNCC (2018, p.10), as três últimas competências gerais dizem respeito ao desenvolvimento socioemocional dos alunos: $8^{\text {a: }}$ conhecer-se, reconhecer suas emoções e as dos demais; 9a: desenvolver empatia, diálogo, resolução de conflitos e cooperação; 10ª: agir de modo autônomo, responsável, flexível, resiliente, determinado ao tomar decisões baseando-se em princípios éticos, democráticos, inclusivos, sustentáveis e solidários. Acredita-se que essas competências foram contempladas e desenvolvidas ao longo do trabalho que esta pesquisa acompanhou, no entanto, as ferramentas de avaliação construídas e amplamente validadas por pares ainda são escassas e carecem de atenção de instituições, docentes e pesquisadores.

O Instituto Ayrton Senna tem desenvolvido, desde 2011, uma metodologia de análise que está sendo aplicada com essa função em parceria com a OCDE, baseada na Teoria do Big Five, que distingue cinco domínios de experiência: abertura a novas experiências, consciência, extroversão, amabilidade, estabilidade emocional. Depois de várias elaborações, em 2013, no Rio de Janeiro, foi aplicada avaliação do sistema SENNA (sigla em inglês para “Avaliação Nacional de Habilidades Socioemocionais ou Não-cognitivas”), que contém 92 itens e cruza dados socioeconômicos, cognitivos e informações sobre o ambiente de aprendizagem 9 .

No caso desta pesquisa, os avanços em relação a autonomia, resolução colaborativa de problemas, diálogo, autoconhecimento e imagens que os alunos fazem de si e do seu desempenho, embora visíveis por quem acompanha os alunos, não passaram por uma matriz específica de avaliação, mas pode ser um próximo passo tendo em vista as discussões que podem ainda ocorrer no ambiente da instituição que sediou a pesquisa.

${ }^{9}$ Disponível em: http://porvir.org/especiais/socioemocionais/. Acesso em: 03 mar. 2019. 


\section{Considerações finais}

A presente pesquisa objetivou refletir sobre o uso de metodologias ativas, em especial, a resolução de situação-problema, em salas de aula de produção escrita da $3^{a}$ série do ensino médio por meio de uma pesquisa-ação. Além disso, também pretendeu construir reflexões e propor um modelo de sequência didática para que as experiências com a pesquisa pudessem ser socializadas com um grupo de professores de redação da mesma instituição. Em relação ao primeiro objetivo, acredita-se que ele foi alcançado e demonstra como é possível atingir resultados qualitativos e até quantitativos com metodologias não tradicionais. Vale ressaltar que, depois de concluída a pesquisa, ficou claro que o trabalho com a autonomia deve apenas ser reforçado e concluído na $3^{\mathrm{a}}$ série do ensino médio, mas se ele não for devidamente iniciado antes, no mínimo no $9^{\circ}$ ano do ensino fundamental, o desempenho dos alunos sempre será atingido após ultrapassarem-se as barreiras da insegurança e do medo do erro por parte dos alunos e do professor. Em relação ao desenvolvimento das suas competências socioemocionais, seu avanço foi nítido pelas observações e pela escuta da professorapesquisadora e da autoavaliação dos próprios alunos após as rodadas de simulação, mas numa etapa futura do trabalho seria interessante a construção de uma matriz de avaliação dessas competências, contando, inclusive, com a colaboração dos próprios alunos. Por fim, em relação ao segundo objetivo, o instrumento para discussão das sequências didáticas foi construído e deve ser validado junto aos demais professores, por meio de situações formativas em que possam refletir juntos sobre o uso de metodologias ativas e da abordagem de resolução de situação-problema. Esse corpo docente pode também discutir as adaptações necessárias aos grupos definidos de alunos e colaborar para a construção da matriz de avaliação de competências socioemocionais, contribuindo para a instrumentalização, com intencionalidade e contextualização, das práticas de formação do cidadão integral, tão almejada por toda a sociedade.

AGRADECIMENTOS: Agradecimento ao Instituto de Pesquisas e Educação Continuada Economia e Gestão de Empresas, Pecege, na pessoa do Professor Doutor Pedro Valentim Marques pelo apoio e incentivo, e a Fundação de Estudos Agrários Luiz de Queiroz - FEALQ pelo auxílio financeiro concedido. Trabalho premiado como melhor monografia defendida no curso de MBA em Gestão Escolar USP/ESALQ no XIII SIM, realizado em dezembro/2019. 


\section{REFERÊNCIAS}

ARAÚJO, U.F. Temas transversais, pedagogia de projetos e mudanças na educação. São Paulo: Summus, 2014.

BERBEL, N.A.N.; SÁNCHEZ GAMBOA, S.A. A metodologia da problematização com o Arco de Maguerez: uma perspectiva teórica e epistemológica. Filosofia E Educação, Campinas, v. 3, n. 2, p. 264-287, 27 nov. 2011.

BOURDIEU, P. Escritos de educação: organização de Maria Alice Nogueira e Afrânio Catani. Petrópolis: Vozes, 2011.

BRASIL. MINISTÉRIO DA EDUCAÇÃO (MEC). Base nacional comum curricular, 2018. Disponível em: http://basenacionalcomum.mec.gov.br/wp content/uploads/2018/12/BNCC_19dez2018_site.pdf. Acesso em: 02 mar. 2019.

FRANCO, M.A.S. Pedagogia da Pesquisa-Ação. Educação e Pesquisa, São Paulo, v. 31, n. 3, p. 483-502, set./dez. 2005.

GUIMARÃES, Y.A.F.; GIORDAN, M. Instrumento para construção e validação de sequências didáticas em um curso a distância de formação continuada de professores. In: VIII Encontro Nacional de Pesquisa em Educação em Ciências e I Congresso Iberoamericano de Educação em Ciências, 2012, Campinas. Atas do [...]. Campinas, 2012. P. 1-12.

INSTITUTO NACIONAL DE ESTUDOS E PESQUISAS EDUCACIONAIS ANÍSIO TEIXEIRA (INEP). Redação no Enem 2018: cartilha do participante, 2018. Disponível em: http://download.inep.gov.br/educacao_basica/enem/guia_participante/2018/manual_de_redac ao_do_enem_2018.pdf. Acesso em: 02 mar. 2019.

LACERDA, D.P. et al.,. 2013. Design Science Research: método de pesquisa para a engenharia de produção. Gest. Prod, São Carlos, v. 20, n. 4, p. 741-761, nov. 2013.

MACEDO, L. A situação-problema como avaliação e como aprendizagem. p. 29-36. In: Moraes, J.S. Exame Nacional do Ensino Médio (ENEM): fundamentação teóricometodológica. Brasília: INEP/MEC, 2005.

MACHADO, N.J. Educação: cidadania, projetos e valores. São Paulo: Escrituras Editora, 2016

MARQUES, R.N. Formação continuada de professores em uma perspectiva da interação formador-formando. Orientadora Prof. ${ }^{a}$ Dr. ${ }^{a}$ Sônia Maria Duarte Grego. 2012. 116p. Tese (Doutorado) - Universidade Estadual Paulista, Araraquara, SP, 2012.

MEIER, M.; Garcia, S. Mediação da aprendizagem: contribuições de Feuerstein e de Vygotsky. Curitiba: Edição do autor, 2011.

MORAN, J.M. A educação que desejamos: novos desafios e como chegar lá. 2. ed. Campuinas, Papirus, 2007.

MOREIRA, M.A. Aprendizagem significativa., Brasília: Editora da UnB, 1999. 
ORGANIZAÇÃO DAS NAÇÕES UNIDAS PARA A EDUCAÇÃO, A CIÊNCIA E A CULTURA (UNESCO). Educação para a cidadania global: preparando alunos para os desafios do século XXI, 2015. Disponível em: http://www.unesco.org/new/pt/brasilia/aboutthis-office/single-view/news/global_citizenship_education_preparing_learners_for_the_cha1/. Acesso em: 02 mar.2019.

\section{ORGANIZAÇÃO PARA A COOPERAÇÃO E DESENVOLVIMENTO ECONÔMICO}

(OECD). PISA 2015: exemplos de itens liberados de resolução colaborativa de problemas RCP1, 2015. Disponível em:

http://download.inep.gov.br/acoes_internacionais/pisa/itens/2015/itens_liberados_rcp_pisa_2 015.pdf. Acesso em: 03 mar. 2019.

ORLANDI, E. P. Interpretação: autoria, leitura e efeitos do trabalho simbólico. Petrópolis: Vozes, 1996.

SCHÖN, D. A. Formar professores como profissionais reflexivos. In: Nóvoa, A. Os professores e sua formação. Lisboa: Dom Quixote, 1992.

THIOLLENT, M. J. M.; COLETTE, M. M. Pesquisa-ação, formação de professores e diversidade. Acta Scientiarum. Human and Social Sciences, v. 36, n. 2, p. 207-216, 5 dez. 2014.

ZABALA, A. A prática educativa: como ensinar. Tradução Ernani F. da F. Rosa. Porto Alegre: Artmed, 1998.

\section{Como referenciar este artigo}

GUIRADO, Maria Teresa Martins; MARQUES, Rosebelly Nunes; CASTRO, Flávia Pierrotti de. Metodologia de resolução de situação-problema aplicada à aula de produção de texto no ensino médio. Revista Ibero-Americana de Estudos em Educação, Araraquara, v. 15, n. 3, p. 1343-1373, jul./set., 2020. e-ISSN: 1982-5587. DOI: https://doi.org/10.21723/riaee.v15i3.13611

Submetido em: 20/10/2019

Revisões requeridas em: 15/12/2019

Aprovado em: 25/12/2019

Publicado em: 20/02/2020 